\title{
Bentham's Frigidarium: Utilitarianism and Food Preservation
}

\author{
DAVID L. COHEN
}

Jeremy Bentham's Frigidarium manuscripts form a little known excursion by Bentham into the science of food preservation. These little discussed manuscripts are mentioned by Bentham in a letter to his brother Samuel and in two letters to Peter Mark Roget (1779-1869), a precocious physician who received scientific acclaim by the age of 21 and who in October 1800 spent six weeks with Jeremy Bentham discussing Bentham's scheme for the utilization of the sewage of big metropolises and his Frigidarium (related projects). ${ }^{1}$ The manuscripts are rarely mentioned in the literature on Bentham. ${ }^{2}$ Roget himself, referred to them only three times, the last reference written just before Roget began his stay with Bentham. ${ }^{3}$ Samuel Romilly (1757-1818), Roget's uncle, seems to have been aware of Bentham's Frigidarium and rather proud that Bentham saw fit to consult his nephew about it. ${ }^{4}$ The plans were discussed during their six week acquaintance, (although there is no record of what they discussed) Bentham wrote Roget that he felt 'much the want of a confidential friend, whose sympathetic zeal might animate my languor'.5 After this episode, however, the manuscripts are never mentioned again. This essay will do three things. First it will provide some possible reasons why Bentham was interested in refrigeration and why he abruptly ceased to show interest. Second, in order to answer the first question the history of refrigeration will be outlined and the place of Bentham's device in it will be described. Lastly, how the Frigidarium was supposed to work will be explained.

\footnotetext{
${ }^{1}$ W.W. Webb, 'Roget, Peter Mark', Dictionary of National Biography, xlix. 149; The Correspondence of Jeremy Bentham, ed. J.R. Dinwiddy, vi. Oxford, 1984 (The Collected Works of Jeremy Bentham), p. 351 (hereafter Correspondence $(C W)$. Roget stayed at Queen's Square Place and attended a course of lectures by John Abernethy (1764-1831) at St. Bartholomew's Hospital.

${ }^{2}$ There exists only one mention outside the footnotes in Bentham's correspondence, that I know of, in C.K. Ogden, 'Bentham on Invention', Psyche, x (1929), p. 107.

${ }^{3}$ Correspondence $(C W)$, vi. pp. 350-1, 361-3

${ }^{4}$ Although he was quite unsure what the contraption was for, and implied that Bentham was quite secretive about it, probably because of fears about patents: Ibid., p. 224, n1.

${ }^{5}$ Correspondence $(\mathrm{CW})$, vi. p. 348.
} 
Most of the frigidarium manuscripts are rough outlines and sketches of ideas composed between 1794-1809. Bentham himself describes them as in a very crude and imperfect state'. ${ }^{6}$ Little is known about the manuscripts except what is contained in them and the letters to and from Roget. It seems that Bentham envisioned a large underground 'ice-house' in which foods other than grain could be stored for long periods of time. The basic principle would be to exclude heat, but not to freeze, as freezing causes the texture to be 'quite broken up and destroyed'. ${ }^{7}$ Rather, Bentham wished to keep the subject-matter in temperature of not more than 360 Fahrenheit (2.220 Celsius). The objects would be stored in airtight containers. The temperature in the Frigidarium would be preserved by ensuring an 'adequate magazine of ice throughout the year' and through certain chemical reactions that he saw taking place in the pools of water in the Frigidarium storage chambers.

\section{Why the Frigidarium?}

In the manuscripts and in his correspondence Bentham himself gives some reasons why he thought the construction of the Frigidarium would be useful. Indeed, the object of the Frigidarium was outlined rather clearly as 'The Preservation of Animal and Vegetable Substances from all species of Spontaneous decomposition' and the 'Regulation of natural processes depending on particular temperatures'. ${ }^{8}$ Bentham listed under 'Evidence in favour of the profitability/probability of success' that in addition to the preservation of legumes, fruit, milk products, meats and fish the Frigidarium would hasten the ripening of fruits, the brewing of Beer, the fermentation of wine, the drying of wood for musical instruments, the hatching of wood, and preserve dead bodies for a national bank for anatomical study. ${ }^{9}$ In typical fashion, Bentham thought he created a device that would perform not one but a plethora of functions useful to society. In his last letter to Roget on the Frigidarium Bentham outlined its primary purpose, to preserve food from season to season, and even from day to day in the hope that the price of the food would remain constant, since there

\footnotetext{
${ }^{6}$ Ibid.

${ }^{7}$ Ibid., p. 347.

${ }^{8}$ University College London, Bentham Mss (hereafter cited as UC) cvi. 64.

${ }^{9}$ Ibid.
} 
would now be a more constant supply. Bentham seems to have envisioned the Frigidarium as part of some sort of central purchasing agency that would buy the food when it was not too dear and sell it when it was wanted at a rate "profitable to the seller, and yet cheap to the poor'. ${ }^{10}$

The Frigidarium papers were written between 1794 and 1809 during a period of war and food shortages throughout the continent and Britain. The panic from the grain shortage and the subsequent riots in 1795 and $1800,{ }^{11}$ coupled with the widespread perception that conditions of the lower classes had markedly deteriorated, ${ }^{12}$ and the market distortions caused by the war in Europe, ${ }^{13}$ made Bentham realize the vast potential benefits of a method of storing food for long periods of time. The great concentration of people in Urban centres and the massive increase in population noted by Arthur Young as far back as 1771 made the need for a method of preserving food during times of want and the social dangers that would accompany famine, acute. ${ }^{14}$ The dangers of scarcity were well known at the time and in most were minds connected with violent Revolution, something to which Bentham (at that time, at least) was quite unsympathetic. ${ }^{15}$ Bentham probably thought of himself as a latter day Joseph who would, at a profit, store food during the time of plenty for the time of want and thereby save the nation from starvation and keep inflation in check. ${ }^{16}$ Bentham believed that in order to combat food shortage government should encourage the entry of capital into agriculture and seek to provide remedies for local disadvantages of supply; the Frigidarium satisfies Bentham's desires perfectly. ${ }^{17}$ Lastly, at the same time that he was working on the Frigidarium Bentham was writing his papers on the Panopticon and the National Charity Company. It quite easy to see how the long-term storage of food would fit in very well with both projects' requirements of economy.

\footnotetext{
${ }^{10}$ Correspondence $(C W)$, vi. p. 358.

${ }^{11}$ R. Wells, Wretched Faces: Famine in Wartime England 1763-1803, New York, 1988, 1-2; M. E. Rose, The English Poor Law 1780-1930, Newton Abbot, 1971, p. 20.

${ }^{12}$ D. Davies, The Case of Labourers in Husbandry Stated and Considered, London, 1795, p. 6. See also J.R. Poynter, Society and Pauperism, English Ideas on Poor Relief 1795-1834, London, 1969, pp. 52-3.

${ }^{13}$ Ibid. 52.

${ }^{14}$ S. Thorne, A History of Food Preservation, Kirkby Lonsdale, Cumbria, 1986, p. 17; Poynter, p. 45.

${ }^{15}$ For that connection see Edmund Burke, Thoughts and Details on Scarcity, London, 1795; Poynter, Society and Pauperism, pp. 52-3.

${ }^{16} \mathrm{He}$ alludes to something to that effect in a letter to Samuel Bentham, Correspondence $(\mathrm{CW})$, vi. p. 359.

${ }^{17}$ Poynter, Society and Pauperism, p. 121.
} 
Bentham's loss of interest in the eighteen teens ${ }^{18}$ probably has to do with the turning of the tide of the war in Europe in Britain's favour, which was accompanied by fewer food shortages, and new developments in food preservation and cooling that would revolutionize the food industry. These changes would make superfluous the well intended by very amateur forays into refrigeration of someone who confessed never to have seen an icebox and relied only on the theoretical works of chemists, ${ }^{19}$ experiences recorded in travelogues, and his own experiments which remain for the most part indecipherable.

\section{A General History of Refrigeration and Food Preservation}

The ancients knew very well the powers of refrigeration, the first recorded use of an ice house is in a Chinese poem of $1100 \mathrm{BC}$ and the snow trade is as old as the Romans. The ancient Egyptians knew that the vaporization of water caused a net heat loss. The Arabs were the first to discover that when certain salts are added to water the water cools. ${ }^{20}$ The cooling of water and wine by adding various salts was noted by Francis Bacon (1561-1626). Robert Boyle (1627-1691) used salts to freeze water in his Historia Experimentalis de Frigore (1665). Daniel Gabrieli Fahrenheit (16861736) established his thermometer's zero using snow and ammonium nitrate. Blas Villafranca was the first to use the words 'to refrigerate' in 1550 in his Methodus Refrigerandi ex Vocato Slentiro Vinum Aquamque. ${ }^{21}$ The first true refrigerator ${ }^{22}$ was devised by the Scot, William Cullen (1710-1790), who was the first to observe scientifically that the evaporation of ethyl ether is accompanied by a fall in temperature. In 1755 Cullen produced a laboratory set up which permitted him to make ice by evaporation of water under a bell jar under reduced pressure. ${ }^{23}$

\footnotetext{
${ }^{18}$ Bentham maintained a constant interest in the Frigidarium through 1809 , even beginning construction of parts of it, as well as securing a sufficient quantity of ice to maintain it: UC 106-70, pp. 106-71.

${ }^{19}$ Bentham claimed to be 'very slow and awkward' at mathematics: Correspondence $(C W)$, vi. p. 357.

${ }^{20} \mathrm{R}$. Thevenot, A History of Refrigeration Throughout the World, translated by J.C. Fiddler, Paris, 1979, p. 24.

${ }^{21}$ Ibid., p. 24.

${ }^{22}$ By true refrigerator I mean a device that could create 'cold' as opposed to a device that would only maintain the 'cold' that was already present.

${ }^{23}$ Thevenot, History of Refrigeration, p. 28
} 
Before 1875 there were four families of refrigeration machines: those that relied on the compression and evaporation of liquefiable gasses; those that relied on the expansion of precompressed air; absorption machines, and those that relied on the evaporation of water at reduced pressure. The first type of refrigeration machine was most common in Britain, the second in America, and the third in France. ${ }^{24}$ Progress in the science of refrigeration began to accelerate in the late eighteenth century. In 1781 the Italian Tiberio Cavallo (1749-1809), who lived in England from 1771, published in the Transactions of the Royal Society descriptions of his experiments on the lowering of temperatures by the evaporation of several ethers and alcohol. ${ }^{25}$ Erasmus Darwin (1731-1802) observed in 1788 that the expansion of compressed air results in cooling. ${ }^{26}$ Gerald Nairne (1726-1806), a Scot, in 1777 published an idea of putting sulphuric acid under an evacuated bell jar to absorb water vapour and thus accelerate the cooling process caused by water evaporation. ${ }^{27}$ If Bentham was unaware of Cullen, Cavallo, Darwin and Nairne's observations, he was definitely informed of them by Roget who was in close contact with Thomas Beddoes (1760-1808) and Humphry Davy (1778-1829) and was educated in medicine at Edinburgh. ${ }^{28}$ Bentham himself seems to have scoured the scientific literature on this subject reading Lavoisier (17431794), Rumford (1753-1814) and Kirwain (1733-1812). ${ }^{29}$ In 1793, the year before Bentham began to write down his ideas on refrigeration, Thomas More obtained a patent in America for cooling by ice. In 1803 More described his refrigerator, a box cooled by an ice salt mixture. ${ }^{30}$ Finally, in 1810 , the year Bentham ceased to occupy his time with refrigeration, the Scot John Leslie (1766-1832) perfected a laboratory apparatus that was able to procedure 3 kilograms of ice per hour of operation. ${ }^{31}$

Food preservation by means other than thermal control also has a long history. The benefits of smoking, curing, pickling, and salting food were well known in the middle ages. Much of the impetus to preserve food in the eighteenth century came

\footnotetext{
${ }^{24}$ Ibid., p. 39.

${ }^{25}$ Ibid.

${ }^{26}$ Ibid., p. 43.

27 Ibid., p. 47.

${ }^{28}$ Webb, 'Roget', p. 149.

${ }^{29}$ Antoine Laurent Lavoisier, French Chemist and bete noir of the English Chemists of this period (due to his anti-phlogiston stance); Sir Benjamin Thompson, Count von Rumford, inventor, chemist and philanthropist; Richard Kirwan, chemist and natural philosopher. Bentham read his Elements of Mineralogy, 1784, soon after its publication (Correspondence (CW), iii. p. 292), and made great use of Kirwan's ideas on decomposition in his refrigeration manuscripts.

${ }^{30}$ Thevenot, History of Refrigeration, p. 416.

${ }^{31}$ Ibid., p. 47.
} 
from the Navy by the persistence of scurvy. In 1752 James Lind (1716-1794) ${ }^{32}$ connected scurvy with a lack of fruit and vegetables. The Navy began to actively seek means of preserving food. Bottling fruit became a well established practice by the mid-eighteenth century. ${ }^{33}$ The Dutch at this time had discovered a way to preserve food covered with hot fat in canisters whose lid had been soldered on just after the cooking had finished. ${ }^{34}$ Bentham was aware of the Dutch advances and their successful use of preserved food in Guiana. ${ }^{35}$ In France, Nicolas Appert (1750-1841) a confectioner near Paris discovered a method of canning that preserved food for many months. In 1810 he published his L'Art de Conserver pendant plusieurs annees toutes les Substances Animales et Vegetales which soon became an international success. ${ }^{36}$ In England the book was published in 1811 as 'The Art of Preserving all Kinds of Animal and Vegetable Substances for Several Years'. Three months after Appert published his book in France a certain Peter Durand in London was granted a patent for the invention of a method of preserving animal and vegetable food and other perishable articles for a long time without perishing, and admitted receiving the invention from a 'certain foreigner living abroad'. Soon canneries were popping up everywhere. $^{37}$

It would seem that Bentham was caught in the middle of a movement that was searching for methods of food preservation. His refrigerator like More's in America was an ice box whose humidity and temperature was regulated by vapours and salts. Bentham's loss of interest in 1809 makes sense in light of the revolution in ice production and canning that swept Europe the following year. Why should he spend his inexpert time on such pursuits when his idea was no longer state of the art and it seemed that it was now possible to can foods so they need not be refrigerated, and to make true refrigerators instead of steady-state ice boxes.

\section{The Functioning of the Frigidarium and its component parts explained}

\footnotetext{
32 James Lind of Haslar was the cousin of John Lind (1731-81), Bentham's close friend. Samuel Bentham was in friendly contact with James Lind.

${ }^{33}$ Thorne, Food Preservation, 21-4.

${ }^{34}$ Ibid. 25.

${ }^{35}$ UC cvi 64.

${ }^{36}$ In France it went into seven editions by 1832. Appert's forenames are not known with certainty and include: Nicholas, Francois, and Charles.

${ }^{37}$ Thorne, Food Preservation, pp. 28-37.
} 
The Frigidarium took its name from the cooling off room in Roman Baths. It was a partly submerged bubble that was covered with earth in a kind of mound that acted as insulation. Stairs would lead down to the two main chambers. There would be a double air lock system, one at the beginning of the stairs down and one before entry into the first chamber, the ante-Frigidarium. This first chamber was a cooling off room where the objects to be stored would be slowly cooled in order to minimize the amount of ice lost. Water collected from the melted ice would be applied to the object to be stored, the evaporation of which would cool it off even more. ${ }^{38}$ The next chamber was the Frigidarium itself which had a viewing table and an elaborate storage system wherein the objects were stored. There were two double glazed windows that looked on to the display table in the Frigidarium from outside the mound. ${ }^{39}$ The storage system, which worked by pulleys, enabled the object to be placed from storage onto the table before the attendant actually entered the mound. ${ }^{40}$ This was done to minimize the amount of time the attendant, a heat producer himself, would be in the Frigidarium. Behind the Frigidarium was an ice receptacle which would be the main cooling agent for the Frigidarium.

In the Frigidarium and ante-Frigidarium chambers were pools called 'Balneums'. These pools of water would steady the temperature by heating or cooling the air of the Frigidarium as the temperature of the air in the Frigidarium fluctuated. Bentham did not think of the Balneums as necessary components of the Frigidarium, rather he saw them as an added insurance against wild temperature fluctuations. ${ }^{41}$ Salts would be added to make the water colder and placed in the open air to absorb the humidity. ${ }^{42}$ The outside of the mound itself would be cooled (and thus cool the inside of the mound) by the nightly evaporation of sewage from nearby cities that would be poured onto it. The sewage would have the additional advantage of fertilizing the plants that would grow on the mound. ${ }^{43}$ In the manuscripts Bentham hinted that the stored objects would be sealed in air-tight containers. This would be accomplished by

\footnotetext{
${ }^{38}$ Ibid.

${ }^{39} \mathrm{UC}$ cvi. 68 , although in UC cvi. 66 he mentions triple glazing.

${ }^{40}$ UC cvi. 66.

${ }^{41}$ UC cvi. 48.

${ }^{42}$ Ibid and UC cvi. 68.

${ }^{43}$ UC cvi. 48.
} 
boiling while sealing or corking in a vacuum. ${ }^{44}$ The Frigidarium was not a true refrigerator since it did not rely on a physical or chemical process to cause the absence of heat (i.e. create 'cold'). Rather it was more of a device that once its contents were cold would keep absent through insulation and chemical and physical processes.

\section{Conclusion}

In a time of food shortages Bentham thought it a very humanitarian if not a prudent and potentially profitable decision to investigate methods of storing foods for long periods of time. The technology of canning and refrigeration was sufficiently developed to allow Bentham to have an amateurs go at designing a public works type ice box that relied on sewage and ice to keep sealed goods from spoiling and still turn a profit. A return to relative abundance and revolutions in food preservation made Bentham's amateurish forays seem irrelevant and it is no wonder that he never seriously returned to them.

Copyright (C) 1997, David L. Cohen. This file may be copied on the condition that the entire contents, including the header and this copyright notice, remain intact. It may not be used for commerical purposes without the author's prior consent.

\footnotetext{
${ }^{44} \mathrm{UC}$ cvi. 68.
} 